\title{
Publisher Correction: Comprehensive molecular characterization of mitochondrial genomes in human cancers
}

Yuan Yuan (iD, Young Seok Ju (D), Youngwook Kim (D), Jun Li (D), Yumeng Wang, Christopher J. Yoon, Yang Yang, Inigo Martincorena, Chad J. Creighton (D), John N. Weinstein (D), Yanxun Xu, Leng Han (D), Hyung-Lae Kim, Hidewaki Nakagawa, Keunchil Park (D), Peter J. Campbell (ID, Han Liang (D) and PCAWG Consortium

Correction to: Nature Genetics https://doi.org/10.1038/s41588-019-0557-x, published online 5 February 2020.

This paper was originally published without open access. As of the date of this correction, the paper is available online as an open-access paper under a Creative Commons Attribution 4.0 International License.

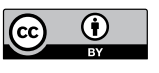

Open Access This article is licensed under a Creative Commons Attribution 4.0 International License, which permits use, sharing, adaptation, distribution and reproduction in any medium or format, as long as you give appropriate credit to the original author(s) and the source, provide a link to the Creative Commons license, and indicate if changes were made. The images or other third party material in this article are included in the article's Creative Commons license, unless indicated otherwise in a credit line to the material. If material is not included in the article's Creative Commons license and your intended use is not permitted by statutory regulation or exceeds the permitted use, you will need to obtain permission directly from the copyright holder. To view a copy of this license, visit http://creativecommons.org/licenses/ by/4.0/.

Published online: 11 February 2020

https://doi.org/10.1038/s41588-020-0587-4

(C) The Author(s) 2020 